\title{
The Effectiveness of E-Advertisement towards Customer Purchase Intention: Malaysian Perspective
}

\author{
Seyed Rajab Nikhashemi ${ }^{1}$, Laily Paim ${ }^{2}$ Saeideh Sharifi fard ${ }^{3}$ \\ , 1,2,3 Department of Resource Management and Consumer Studies University Putra Malaysia (UPM)
}

\begin{abstract}
The primary objective of this study was to examine the effectiveness of E-advertisement on customer purchase intention. Beside, this study examined the effect of mediating and moderating demography factors on customer purchase intention in Malaysia. Data from 570 respondents with previous experience on online purchasing products and services were collected. To do so, SPSS 19 was applied to analyze the collected data. Our findings revealed that service quality, social network and brand recognition can highly influence customers' perception toward web-based advertisement. Consequently, consumers who are more optimistic in web-based advertisement (E-advertisement) have most likely higher intention to online purchase. In other words, the effectiveness of E-advertisement is undoubtedly highlighted in this study. Besides, the results of this study showed that the demography factors cannot mediate the customer perception toward advertisement nor the effectiveness of E-advertisement toward customer purchase intention. On the basis of our results, companies must stress the intrinsic attributes of online advertisement to attract highly-involved consumers and must present a benevolent corporate image for consumers.
\end{abstract}

Keywords- Quality of website, Social network, Brand recognition, Effectiveness of E-advertisement, and Customer perception toward E-advertisement.

\section{INTRODUCTION}

The emergence of internet technology has created a plenty of opportunities for marketer and all which are involved in vertical environment to carry on their business based on web advertisement [27]. With the rapid growth of the Internet and the globalization of the world, companies have accepted and adopted new information and communication technologies in performing their activities It is not only to support their traditional activities, but also to support the new opportunities that have arisen from the Internet. At the moment, the most stands out opportunities are electronic or online advertisement. Most companies established their Website as new channels for business transactions and advertisement, which enable customers to make online purchases through the Web. At the same time, a company who has a website able to access the global market at a low operating cost. In addition, websites provided by the companies usually offer information at depth while providing customers electronic services (e-services) of superior quality by means of Internet interactivity, which has served to boost up competition among companies [12]. Earlier studies discuss about E-marketing and its cornerstone component which basically referring to consumer perspectives, and thus have intrigued scholars to find out more about the characteristics of customers. With this regard, many concepts have been created, such as customer satisfaction, customer loyalty, perceive of e-advertisement efficiency, customer experiences, customer buying behaviour, customer equity, and others. At the same time, the increasing number of online users has caused companies to modify their structures in order to consider both online and virtual conditions. They have been struggling to identify the most important factors (related to customer-based issues) which may have potential affects and benefits to their businesses. Both groups of online buyers as well as sellers know that using online channels can ease the process of purchasing and selling. By considering this as an important factor, many e-marketers and companies tried to transform their business base to online approach. They understood that the traditional way of advertising cannot be the only way of capturing their online customer; therefore, they have integrated online advertisement through virtual environment as well as their own website to market their product and services. Hence, the needs for appropriate advertisement for their particular service and product has arisen, thus make it compulsory for them to select suitable advertisement base on their target market. [26]. It is important to understand how customers perceive or react to web advertising and what components affect their attitudes and behaviors toward products and services as advertised online. Moreover, it would be valuable to know whether the effectiveness of web advertising leads to purchases of the advertised products or services or vice versa. The purpose of this study is to determine the role of internet and effectiveness of web-advertisement towards customer purchase intention in Malaysia. It is too significant for us to identify the perception and attitude of customers toward web-advertisement and its relationship to effectiveness of advertisement which is going to end up with customer purchase intention. In this study a framework has been conducted to figure out the quality of a website, social network and the recognition of brand which were considered under the scope of consumer behaviour that can impact on the attitude of online customer and effectiveness of Web-advertisement. 
The other outstanding aspect of this study is to find out how demographic factor which is incorporated with education, income level, age and gender will impact the online customer's perception towards advertisement and effectiveness of E-advertisement. This study intends to track the contribution of all these factors toward customer purchase intention based on effectiveness of advertisement.[18]

\section{LITERATURE REVIEW}

\section{Web based advertisement ( $\mathrm{E}$-advertisement)}

The emergence of internet technology has created online advertising as the significant approach of commercial communication all over the world. Advertising has been defined as any paid form of non-personal communication of ideas and information about products in the media with the objective of creating brand image [16]. The purpose of advertising is to build up awareness among people regarding particular company's brand, website, or an event in order to stimulate sales and boost up profits. For many years, television, radio, newspapers, and magazines were the only approaches and channels of advertising, but today, online advertising is becoming the main driving force in many advertising initiatives and efforts [16]. Content is one of the important features of the E-advertisement. It delivers the written information regarding particular product or services for online user. [4], point out that short and concise messages lead to effective banner advertisements. [1], figure out that E-advertisers focus and emphasizes on delivering transparent messages on banners in order to draw favorable consumer responses. Online advertising that focuses on content generally uses simple and static text because it loads faster than pictures and multimedia files (Moses, 2009). For instance, Google focuses on content by using very clear and plain html format to hold the basic ethos of its sites [16].

The company has managed to attract a wide range of consumers who perceive the published content as concise and [1]. Online Publishers Association (2008) found that $66 \%$ of online consumers do remember advertised messages on content websites and are likely to develop brand favorability and purchase intention. Meanwhile, [9], revealed that companies which focusing merely on content may attract a small group of potential customers. The study of consumer attitude is an integral part of advertising literature. [11], stressed that understanding consumers' profile, behavior, and attitude are utmost important key in developing effectiveness of advertisement strategy. Pictures can be considered as another component of E- advertisement which can be applied in advertisement to increase effectiveness. Pictures and images can make advertisements turn out to be more attractive to potential customers [28]. In fact, [17] identified that pictures are more effective than content in grabbing the attention of the online customer through E-advertisement. The major drawback of incorporating pictures in online advertising is the time taken to download them. Research has shown that the average person spends about 30 seconds on a webpage before clicking onto another site; hence, pictures that take more than 15 seconds to download may not reach their audience [1]. Multimedia is a form of expression describing elements of online content such as audio, video, and animation [25]. According to [32], animation is one of the innovative features that improve the design and interactivity of online advertisements, particularly the banner advertisements. Animation incorporates with moving images and graphics to enhance the presentation of the content. It includes several technological developments involving plug-ins, JAVA script, Flash, and streaming media [31]. [12], found that consumers respond favorably to animated colors, text, and graphics on websites. Therefore, many companies, develop digital video advertisements to increase consumer involvement with their brands. Digital video can be in the form of streaming video, gaming, or music video [25]. [9], suggested that consumers who are engaged in video games are more likely to develop favorable responses to ingame brands. This finding was supported by [31], who found that companies that build thematic connections between the game and the product's brand would invoke a positive influence on consumer attitude towards the brand.

\section{The effectiveness of social network on E-advertisement}

Social networking sites are among the major developments of the web in the twenty-first century. Used by millions of people, SNSs have altered human behavior on the web, resulting in reduced personal inhibitions of sharing information online [14]. A social network can be a group of friends living within a city, or a group of college classmates who remain in frequent contract socially. It can also be a group formed specifically to accomplish a poorly structured set of tasks over time, like the old GBN1 [5]. SNSs are profile-based web sites that allow users to maintain social relationships by viewing, visiting, and sharing their lists of social connections with other members [5]. These sites provide a virtual environment for interaction and communication to take place between family and friends, while at the same time expanding the scope for social discovery by allowing users to find persons based on the keyword descriptions [21]. Social network allows people and companies to socialize on web, makes people dispel their loneliness, create differentiation, and express their feelings and thoughts [18]. In their article, they emphasize that there is no rule on social media and therefore, users want to show their power over there. According to [5], social networking sites are web-based systems that allow users to establish public or semi-public profile on a regular system, help listing the other people who use the same sites 
and users can view and use crosswise passing between their lists of connections and those used by others within this system. As a result, many companies have taken social networking as a right approach to advertise their products and services. Social networks provide multiple ways for members to interact such as through instant messaging, email, video and voice chat, file sharing, blogging and discussion groups. This multi-way flow of information is accomplished through Web technologies, a collection of scripting languages and applications that have fundamentally changed the nature of the Internet from one to many delivery devices to many global communication experience (Scan Safe White Paper, 2008).

\section{Impact of Website quality on customer perception towards E-advertisement}

Previous researches have figure out the way to assess website quality that should incorporated with many dimensions $[13,2,19,6,31,9]$. The dimensions which were identified by scholars can be classified in different types of category such as quality of information which is necessary to provide in the website, security of website which is one of the critical factor in this case, ease of use, enjoyment, and design of website which all of these mentioned the elements that can lead to positive perception of customer towards E-advertisement [13]. In an information-rich environment, people have access to almost any amount of information they required.

\section{Website Design Effectiveness}

The design of business to customer websites plays a significant role in grabbing attention and delivering good perception of advertisement to stimulate purchase intention of E-customers. The design of a website is as important as the content of the website [6]. Web design has been highlighted as one of the factors which contributed strongly to website quality; therefore online sellers will have to take this critical factor into consideration as it can increase the number of visitors to their websites. As a result, the effectiveness of advertisement can influence on the consumer purchase intention towards that particular product or services. One of the most important characteristics of B2C websites is it is easy to use. Complicated B2C websites can be considered as a barrier for users and it imparts a negative impact on consumers' purchase intention [23].

\section{Website Security and Privacy Effectiveness}

The threat of security has been defined as a certain circumstance and situation, or event with the potential to cause economic hardship to data or network resources in the form of damage, distraction, disclosure, and modification of data, rejection of service, fraud, waste as well as abusive [34]. The concept of security of the website is uses online channel to identify his or her favorite products or services [3]. Security is a kind of shelter for protection of all elements within the website [16]. For all businesses conducted over the net, internet security has become the focal point ensuring wide participation of the information society [34]. Security is one of the most challenging issues facing the internet and merchants today. It is undoubtedly as the most wellknown topic in electronic commerce and has frequently been written about by researchers such as, [27 and 10]. Security of the systems is one of the most important issues, and it is one of the biggest barriers which can prevent consumers from purchasing online. [7] also backed up the idea that online retailers need to build secure websites since internet user's fear and hesitate to purchase products or any services online because of the security concerns. Therefore, applying web based advertisement should consider the security concern while they have intention to approach to their target market via online advertisement. [33]

\section{Information quality}

In assessing the contribution and the significance of information systems in any sort of organization, [13], has paid close attention on the process itself, which is a productivity model for computer systems. On the other hand, other researchers have developed multiple measures of system quality. For instance, [34], used several items to measures MIS appreciation among users. However, the items in his study included reliability of the computer system, online response time, ease of terminal use, and a few other factors. Similarly, [33] stated that several system characteristics and factor should incorporate in the measure of system quality. These system features include the content of the database, aggregation of details, human factors, response time, and system accuracy. Furthermore, [7], suggested that data currency, response time, turnaround time, data accuracy, reliability, completeness, system flexibility, and ease of use as part of a "formative evaluation" scheme to measure system quality. Although information quality is a slippery subject, evaluating the information quality of a website based on four parameters namely accuracy, integrality, relevant and updates timely. Accuracy: Accuracy describes information that is factually irrefutable.

\section{Brand Recognition}

Majority of the companies have recognized the value of brand recognition such as McDonalds has their arches, Goodyear has its blimp and AOL has its distinctive pyramid. While many people maintain that the Internet creates a level playing field with the larger companies, brand recognition is often overlooked. Larger 
companies do the majority of their advertising offline. Sure, they will reference their web sites in their ads, but are not completely dependent on web advertising. Net based entrepreneurs must also create this brand recognition if they want to succeed. This can be done in a number of ways. Many people, who have local businesses, can promote their web site with their web address on their letter head or business card, but these are not the people that have been discussed in this study. To the people, the web site is simply an offshoot of their existing "brick and mortar" business. This is a good stage to aim for if you do not have any recognition at all. Brand recognition will help people to lean towards the product when given the choice between well-known product and one a person never heard of. At the same time, be remembered that the competitors are also working on brand recognition, which means their brand could be more recognizable. Continue to differentiate the product and be sure to add value to product in order to get to the next stage. [35]

\section{Demography}

Another driver of this study is demographic factor which has been considered as an intervene Another driver of this study is demographic factor which has been considered as an intervene variable in this study. Actually, the difference of demographic in terms of computer user and the Internet are critical because having the ability to use these technologies has become increasingly significant to economic success (demographic differences in the use of computers and the Internet are important because ability to use these technologies has become increasingly critical to economic success [22]. People use the Internet in several different ways and for a variety of reasons (Phelps et al., 2000). There are important differences in the view of Information and Communication Technologies (ICT) between different communities in the society. The level of Internet usage is related to gender [14]. Further research has also shown that the level of Internet usage is directly linked to such variables as age and income. The motives for Internet use are often found to be culture-[7 and 28]. Several other studies have drawn distinctions between the use of social, leisure, and academic Internet use [20]. Many vital studies stated that one of the most significant factors having an influence on Internet use is age factor [8]. For example, young generation and old generation have got different purpose when involving with internet activity. Youth basically spend their leisure time on the internet by playing games, chatting, and related things with entertainment, reading, E-advertisement and etc. Older internet users mostly do buying products online, searching for health related information and e-mailing [26]. Normally, it is mentioning in many articles that the usage of internet and social networking sites among young people are more than older people. But according to [3], the percentage for the younger employees (age $<40$ years) who reported average daily use of Internet more than 3 hours $(45.65 \%)$ is lower than the older employees (age $\geq 40$ years) (54.35\%).. In his survey, [29], states that age is negatively related to usage of the internet in terms of the following activities: messaging, browsing, downloading and purchasing in one of his hypotheses. The results shows that age is negatively correlated with messaging and downloading activities and positively correlated with purchasing activities. It means that younger people use the internet more but older people have greater purchasing power [29].

\section{RESEARCH METHODOLOGY}

The aim of conducting the research is to explore the general and specific issues that influencing on Malaysian purchase intention through internet and web based advertisement (E-Advertisement); hence making this research is a causal one. Although much information is available worldwide in this field of study, it is worth exploring to gain a better understanding about the leverages of internet and web based advertisement on Malaysian customer purchase intention case. A total of 635 sample sizes are found to be adequate for this study. About 585 questionnaires were received. Each of the responses received was screened for errors, incomplete and missing responses. Efforts were also taken to contact the affected respondents through e-mail for clarification and corrections, especially on the missing or blank responses. However, the responses that had more than $20 \%$ of the questions in the survey questionnaire unanswered or incorrectly answered were not considered for data analysis. The responses that had a few blank answers (less than $20 \%$ of the questions) and which involve 5-point interval-scaled questions were assigned with a mid-point scale of 3. After the selection process was carried out, only 570 responses were considered complete and valid for data analysis. This represents a success rate of $90 \%$, which is considered to be good in view of time and cost constraints.

\section{Research framework of the study}

Figure 1 shows the theoretical framework of this study in following page. It can be seen that the Quality of website, social network and Brand recognition are independent, and Customer perception toward Eadvertisement and Effectiveness of E-advertisement have considered as a mediator factors; Demography considered as an intervene factor and finally customer purchase intention has been considered as a dependent variable. 


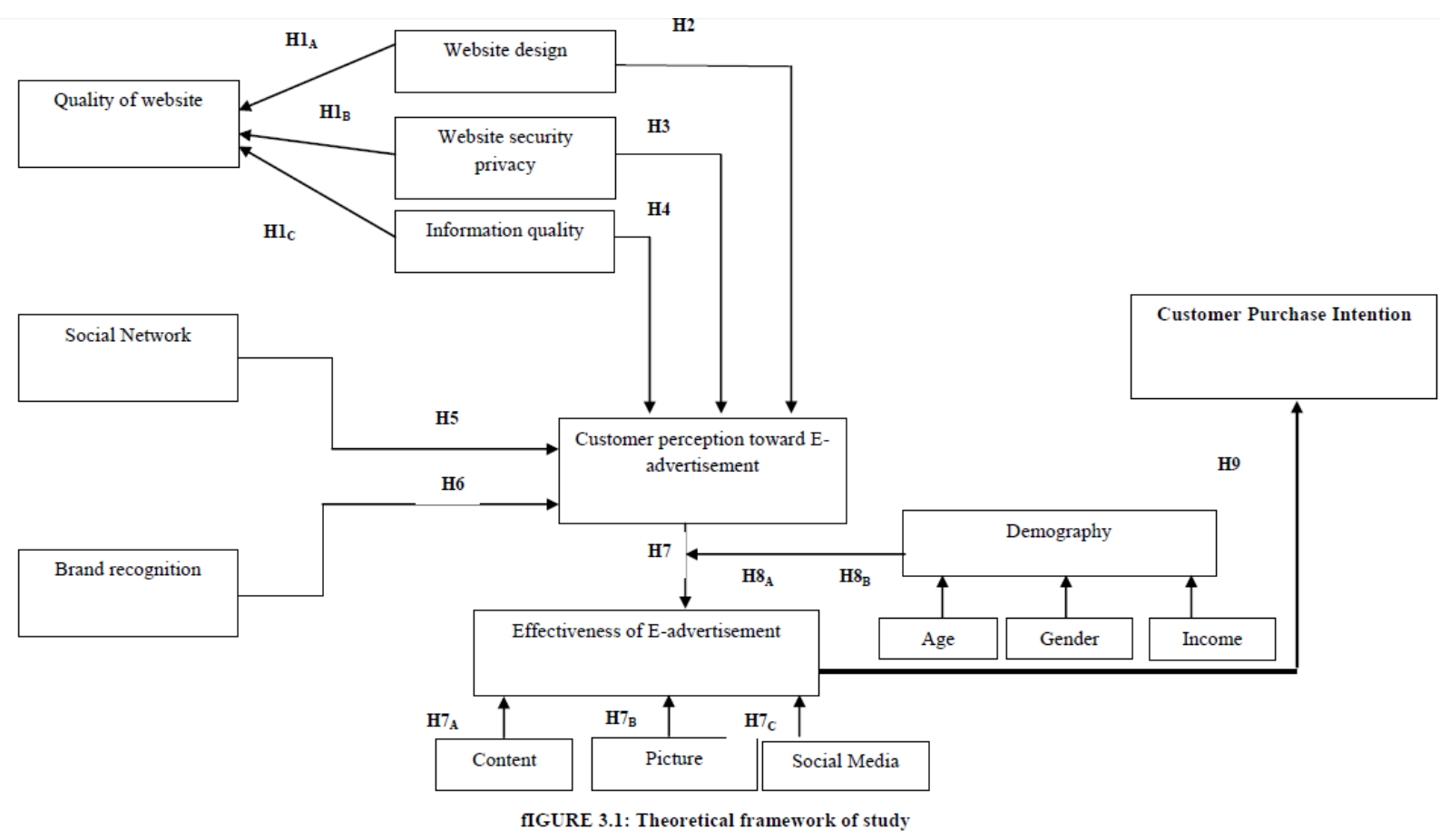

\section{Hypothesis of the Study}

A hypothesis is a logically conjectured relationship between two or more variables expressed in a form of a testable statement. The aim of this study is to figure out the influence of internet and E-advertisement effectiveness toward Malaysian customer purchase intention. The research hypothesis has adapted based on the literature hence the variables have returned as follow.

$\mathbf{H 1}_{\mathrm{A}}$ : There is significant relationship between Website design and website quality.

$\mathbf{H 1}_{\mathbf{B}}$ : There is significant relationship between Website security \& privacy with website quality.

$\mathbf{H 1}_{\mathrm{C}}$ : There is significant relationship between information quality and website quality

H2: There is significant relationship between Website design and customer perception toward E-advertisement.

H3: There is significant relationship between Website security \& privacy with customer perception toward Eadvertisement.

H4: There is significant relationship between information quality and customer perception toward Eadvertisement.

H5: There is significant relationship between Social network and customer perception toward E-advertisement.

H6: There is significant relationship between Brand recognition and customer perception toward Eadvertisement.

H7: There is positive relationship between Customer Perception toward E advertisement An effectiveness of Eadvertisement.

$\mathbf{H 8}_{\mathrm{A}}$ : Demographic factor has got significant influence on customer perception toward E-advertisement.

$\mathbf{H 8}_{\mathrm{B}}$ : Demographic factor has got significant influence on effectiveness of E-advertisement.

H9 $\mathbf{A}_{\mathrm{A}}$ There is significant relationship between Content and effectiveness of E-advertisement.

$\mathbf{H} 9_{\mathbf{B} \text { : }}$ There is significant relationship between picture and effectiveness of E-advertisement.

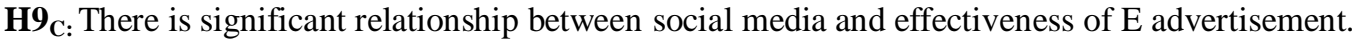

H9: There is significant relationship between effectiveness of E-advertisement and customer purchase intention.

\section{Reliability Test}

\section{RESULT AND DISCUSSION}

The reliability statistics predicts the degree of consistency among the variables being tested (Babbie, 2001). The main reason for performing this test is to ascertain that the measurement taken at any time is always reliable whereby the internal consistency of the variables is tested. This consistency is measured by the value of Cronbach Alpha, which with the value 0.70 or higher represents acceptable reliability (Hair et al., 1998). The table below represents the reliability analysis of all the variables which used in this study and are represented in 1. In order to look at the reliability of the research, the statistics value of Cronbach Alpha of 70 is considered essential for any research, as proposed by Nunnally (1978). Dependability of data will be determined using 
SPSS version 19. According to the results of Cronbach's alpha test total scale of reliability for this study varied from .645 to .846 . This result indicated an overall higher reliability factor. As a result, reliability of this study is substantial, as the highest reliability value that can be achieved is 1.0.

Table 1: Reliability Test

\begin{tabular}{lllr}
\hline Scale & Eigen Value & $\begin{array}{l}\text { Cronbach's } \\
\text { Alpha }\end{array}$ & $\begin{array}{l}\text { No of } \\
\text { Items }\end{array}$ \\
\hline Website design & 8.555 & 0.645 & 2 \\
\hline Website quality \& privacy & 2.215 & 0.751 & 3 \\
\hline Information quality & 2.877 & 0.798 & 2 \\
\hline Social network & 1.761 & 0.845 & 5 \\
Brand Recognition & 1.497 & 0.823 & 4 \\
\hline Customer Perception toward E-advertisement & 1.397 & 0.846 & 4 \\
\hline Effectiveness of advertisement & 1.273 & 0.830 & 5 \\
\hline Demographic & 1.114 & 0.803 & 5 \\
\hline Customer purchase intention base on E-advertisement & 1.090 & 0.744 & 5
\end{tabular}

\section{Factor Analysis}

Factor analysis has been employed to explore the underlying factors associated with 25 items by using Principal Component Analysis (PCA). Bartlett's Test of Sphericity was applied to the constructs validity. Then again the Kaiser-Mayer-Olkin measure of sampling adequacy employed to analyze the strength of association among variables. The Kaiser-Mayer-Olkin measures of sampling adequacy (KMO) were first computed to determine the suitability of using factor analysis to predict whether data are suitable to perform factor analysis or not.

Generally KMO is used to assess which variables need to drop from the model due to multi collinearity. The value of KMO varies from 0 to 1 and KMO overall should be .60 or higher to perform factor analysis. If not then it is necessary to drop the variables with lowest anti image value until KMO overall rise above .60. Result for the Bartlett's Test of Sphericity and the KMO reveal that both were highly significant and concluded that this variable was suitable for the factor analysis. They also suggested that variables with loading greater than 0.30 are considered significant, loading greater than 0.40 more important and loading 0.50 or greater are very significant. In this study, the general criteria were accepted items with loading of 0.60 or greater. Not a single factor had been dropped out under this circumstance. The higher loading (factor) indicates the stronger affiliation of an item to a specific factor.in our study Factor analysis has successfully reduced the variables influencing on customer purchase intention into smaller number of components respectively These components are renamed suitably to represent the items belonging to the respective groups. Based on below result, nine factors are extracted using the Oblimin rotation method that converges after 14 iterations. The factors are found to significantly explain the pattern of correlations within its set of variables since it have Kaiser-Meyer-Olkin (KMO- Table 2) value of 0.867 , as a measure of sampling adequacy which is above 0.7 with Bartlett's test of Sphericity value of zero.

Table 2: KMO and Bartlett's Test

KMO and Bartlett's Test

Kaiser-Meyer-Olkin Measure of Sampling Adequacy.

.867

Bartlett's Test of Sphericity

$\begin{array}{ll}\text { Approx. Chi-Square } & 3748.008 \\ \text { df } & 435 \\ \text { Sig. } & .000\end{array}$


Table 3: Factor Analysis of Internet technology and the effectiveness of E-advertisement towards CPI

Dimension and items

Factor

Loading

Quality of Website

Attractiveness of website design can influence on perceived website quality.

I feel trust and feel secure while I am visiting from that company which have provided secure website

The web site provides various types of credit cards for payment (e.g. Visa, MasterCard, Diners, and American Express

Information quality is significant factor for considering the quality of website and it make customer to be more effected by advertisement

I believe that the sort of design which is used in website can grab the attention of customer and make them satisfy

Effectiveness of W.Q on customer advertisement perception

The ads which have returned in website which has applied sophisticated design will definitely influence on customer

I am more curies to those website ads which have high quality design.

I am so concern about security of website so I am more interested to go through that web advertisement which already has assured the security for their online users.

0.818

Information quality is significant factor for considering in web base advertisement

\section{Social network}

I do read product reviews through social networking sites before purchasing the product

Social networking sites are a good approach to stimulate customer positive perception toward E-advertisement.

Do you agree that social networks would be the best advertisement tool in the future?

There are sufficient advertisement about products and services on social networking sites which can improve the effectiveness of advertisement.

Do you agree that social networks would be the best advertisement tool in the future?

\section{Brand recognition}

I do prefer to consider that advertisement which is belonging to branded product is more effective to stimulate customer purchase intention.

Most often I use branded product and services.

Good brand image always associate with purchase intention.

Effectiveness of E-advertisement \& Perception of customer toward E-advertise Multimedia features in online advertisements give consumers a positive feeling toward the product or service.

Multimedia features in online advertisements will stimulate consumers to learn more about the product or service.

Pictures in online advertisements give consumers a positive feeling toward the product or service

Pictures help generate favorable consumer response to the brand of the product or service.

Contents in online advertisements give consumers a positive feeling toward the product or service.

Contents in online advertisements will persuade consumers to click on the advertisement.

Consumers will consider purchasing the product or service based on the contents in the online advertisement. 


\section{Demography}

Social network has not influence on purchase intention base on gender.

I believe age has strong contribution on Effectiveness of advertisement.

I believe income has strong contribution on customer perception toward $\mathrm{E}$ advertisement.

I believe income has strong contribution on Effectiveness of advertisement.

\section{Customer Purchase intention}

The effective advertisement would result to purchase

Most of web based advertisement influence on my purchase intention

\section{Regression Analysis}

This section highlighted the consequences for regression analyses of the seven variables examined in this study. This analysis enables the hypotheses testing process whereby the results achieved shall be used to decide which hypothesis to be accepted or rejected And one other extra analysis which we have done in this study is regression analysis separately for each of our variables (Website quality Effectiveness of W.Q on customer advertisement perception, Demography, Social network, Brand recognition, Effectiveness of Eadvertisement \& Perception of customer toward E-advertise And Customer Purchase intention) and base on the regression analysis we have supported that whatever factors underlying for each dependent variables have strong contribution with their independent variables as their $\mathrm{p}$-Value all are below $<0.05$ and the results have return in Table 4, 5, 6, 7, 8, 9, 10, and 11

\section{Table 4 Result of multiple regressions output for Website quality}

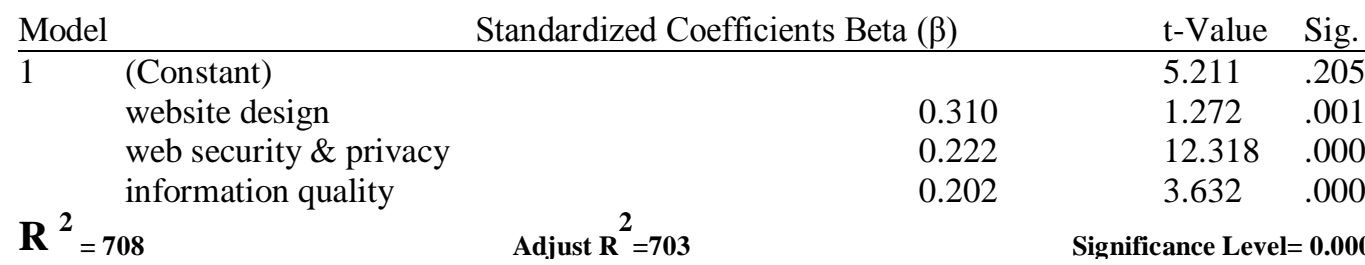

Table 5 Result of multiple regressions output for Social network

\begin{tabular}{llccc} 
Model & \multicolumn{2}{c}{ Standardized Coefficients Beta $(\beta)$} & t-Value & Sig. \\
\hline $1 \quad$ (Constant) & & 11.997 & .063 \\
& & & & \\
website design & $\mathbf{2}$ & 0.683 & 12.922 & .000
\end{tabular}

Adjust $\mathbf{R}^{2}=764 \quad$ Significance Level $=0.000$

Table 6 Result of multiple regressions output of Brand Recognition

\begin{tabular}{|c|c|c|c|}
\hline Model & Standardized Coefficients Beta $(\beta)$ & t-Value & Sig. \\
\hline $1 \quad$ (Constant) & & 5.211 & .016 \\
\hline Brand Recognition & 0.543 & 1.272 & .000 \\
\hline
\end{tabular}


Table 7 Result of multiple regressions output of Customer perception towards Eadvertisement

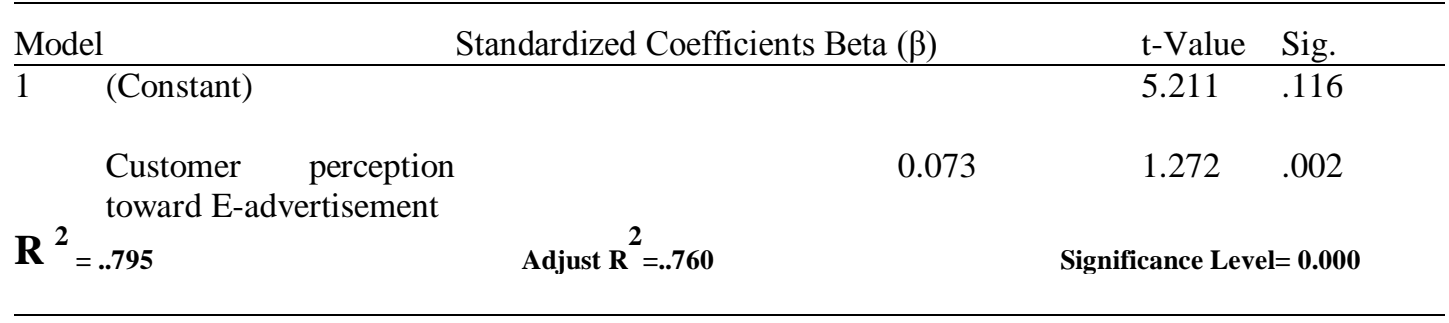

Table 8 Result of multiple regressions output of Customer perception towards Eadvertisement

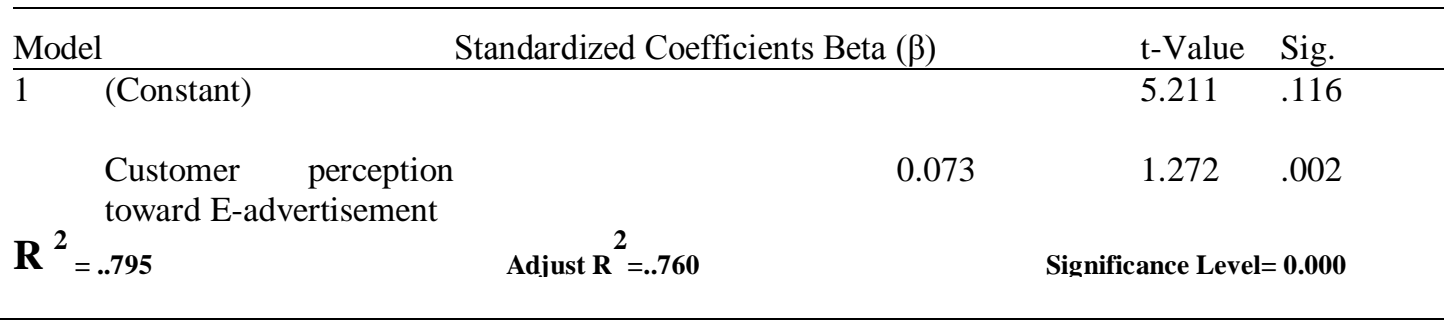

Table 9: Regression output of demographic towards customer perception on Eadvertisement

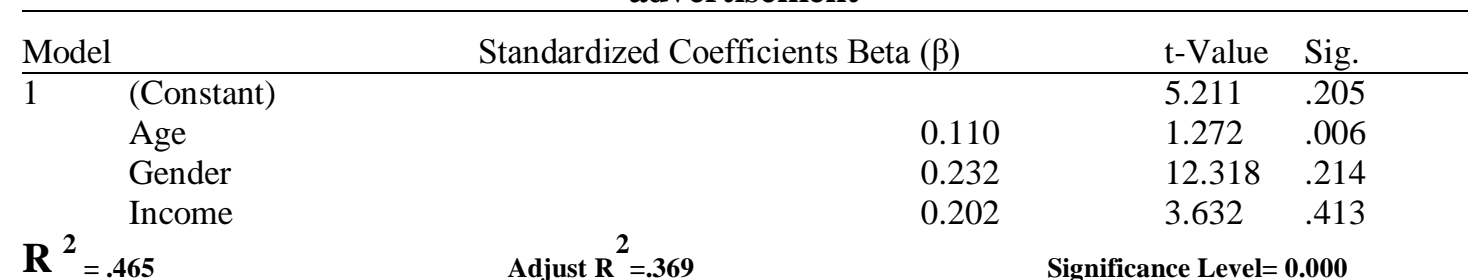

Table 10: Regression output of demographic on effectiveness of E-advertisement $t$

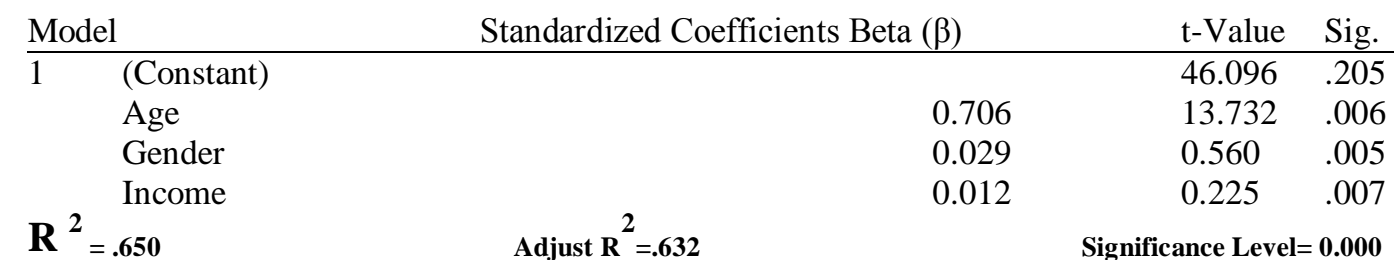

Table 11: Output of E-advertisement effectiveness component

\begin{tabular}{llcccc} 
Model & & Standardized Coefficients Beta $(\beta)$ & t-Value & Sig. \\
\hline $1 \quad$ & (Constant) & & 0.906 & 46.096 & .405 \\
& Content & & 0.129 & 1.230 & .000 \\
& Picture & & 0.412 & 12.225 & .003 \\
& Social Media & & & Significance Level= $\mathbf{0 . 0 0 0}$
\end{tabular}


Table 12 Output of E-advertisement effectiveness on customer purchase intention

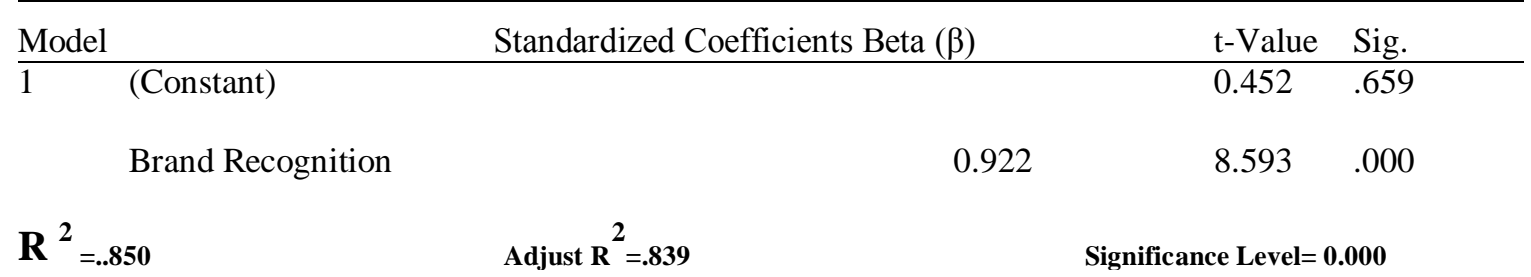

Summary of Hypothesis

From the analysis, it is proved that the all item which have used in the questionnaire are reliable and valid. In summary, it can be concluded that all the hypothesis which we constructed base on literature review supported except $\mathbf{H 8}_{\mathbf{A}}$ (demography part A) which has rejected. This is because the independent variable in each hypothesis is found to have positive significant relationship with the respective dependent variable. However, the strength of the relationship different for every hypothesis. Website quality and its component have positive influence on customer perception toward advertisement as well as social network and brand recognition. Also the other significant factors and hypothesis which has made this study more interesting are the customer perception toward e-advertisement which strongly influence on the effectiveness of E-advertisement and in this study even we haven't overlook the role of demographic factor as an intervene on effectiveness of eadvertisement and customer perception toward E-advertisement, more interestingly we figure out that demographic intervene factor has got influence on advertisement effectiveness and in the contrary it doesn't have influence on customer perception toward E-advertisement, finally we identified that the influential and effective E-advertisement contributes a lot to stimulate customer purchase intention.

Table 13: Hypothesis Summary

Number of Hypothesis

Finding

\begin{tabular}{|c|c|c|}
\hline $\begin{array}{l}\mathbf{H} \mathbf{1}_{\mathrm{A}} \\
\mathbf{H} \mathbf{1}_{\mathrm{B}}\end{array}$ & $\begin{array}{l}\text { There is significant relationship between Website design and website quality. } \\
\text { There is significant relationship between Website security \& privacy with website quality }\end{array}$ & $\checkmark$ \\
\hline $\mathbf{H 1}_{\mathrm{C}}$ & There is significant relationship between information quality and website quality & $\checkmark$ \\
\hline $\mathbf{H} 2$ & $\begin{array}{l}\text { There is significant relationship between Website design and customer perception toward } \\
\text { E-advertisement. }\end{array}$ & $\checkmark$ \\
\hline H3: & $\begin{array}{l}\text { There is significant relationship between Website security \& privacy with customer } \\
\text { perception toward E-advertisement. }\end{array}$ & $\checkmark$ \\
\hline H4 & $\begin{array}{l}\text { There is significant relationship between information quality and customer perception } \\
\text { toward E-advertisement. }\end{array}$ & $\checkmark$ \\
\hline H5 & $\begin{array}{l}\text { There is significant relationship between Social network and customer perception toward } \\
\text { E-advertisement. }\end{array}$ & $\checkmark$ \\
\hline H6 & $\begin{array}{l}\text { There is significant relationship between Brand recognition and customer perception } \\
\text { toward E-advertisement. }\end{array}$ & $\checkmark$ \\
\hline H7 & $\begin{array}{l}\text { There is positive relationship between Customer Perception toward E advertisement } \\
\text { An effectiveness of E-advertisement }\end{array}$ & $\checkmark$ \\
\hline $\mathbf{H 8}_{\mathrm{A}}$ & $\begin{array}{l}\text { Demographic factor has got significant influence on customer perception toward E- } \\
\text { advertisement. }\end{array}$ & \\
\hline $\mathbf{H 8}_{\mathrm{B}}$ & Demographic factor has got significant influence on effectiveness of E-advertisement. & Rejectec \\
\hline H9: & There is significant relationship between Content and effectiveness of E-advertisement & $\checkmark$ \\
\hline H9 & There is significant relationship between picture and effectiveness of E-advertisement. & $\checkmark$ \\
\hline H9 $9_{\mathrm{C}}$ & $\begin{array}{l}\text { There is significant relationship between social media and effectiveness of E- } \\
\text { advertisement. }\end{array}$ & $\checkmark$ \\
\hline H9 & There is significant relationship between effectiveness of E-advertisement and customer & $\checkmark$ \\
\hline
\end{tabular}
purchase intention.

\section{CONCLUSION}

As Internet shopping websites proliferate throughout the world, the number of Internet shoppers is increasing precipitously. However, Internet shopping businesses cannot survive without understanding the mechanism of consumers' repurchase intention; hence the E-advertisement (web based advertisement) hasn't been overlooked among the marketers. The main focus of this study was to find out the effectiveness of E- 
advertisement as well as attributes of web advertisement on a customer's purchase intention, we have considered quality of website, Social network and Brand recognition can impact positively on customer perception toward web based advertisement (E-advertisement) and these factors can function as an external stimuli which has provided by vendors. However logically we linked the effectiveness of E-advertisement with positives perception of customer toward E-advertisement. By linking the customer perception toward Eadvertisement and the effectiveness of E-advertisement we evaluate the moderation effect and mediating effect of demography toward customer purchase intention and we find out demography does not have any impact on the effectiveness of E-advertisement and customer perception toward E-advertisement. The result of this study demonstrate that website quality, social networks brand recognition, customer perception toward web advertisement and effective advertisement have positive impact on customer purchase intention and demography factors in this case does not effect on customer purchase intention.

\section{REFERENCES}

[1] Adam, R. (2003). www.advertising: Advertising and Marketing on the World Wide Web.

[2] Aladiwani, Adel M. and Prashant C. Palvia, "Developing and Validating an Instrument or Measuring User-Perceived Web Quality," Information \&Management, 39 (6), 2002,467-76.

[3] Anda "E-satisfaction A Comprehensive Framework", Second International Conference on Internet and Web Application and Service (ICIW'07), 13(19), 2007, 55-60.

[4] Baltas, G. "Determinants of Internet advertising effectiveness: An empirical study", International Journal of Market Research" 45(2), 2003, 505

[5] Boyd, D. and Ellison, N, "Social network sites: definition, history, and scholarship", Journal of Computer-Mediated Communication, 13 (1), 2007, 210-218

[6] C. Ranganathan and Shonha Ganapathy. "Key Dimension of Business to Customer Website", Journal of Information and Management, 39 (24), 2002, 457-465.

[7] Choi, Junho, James Watt, Ad Dekkers, and Sung-He Park (2004) "Motives of Internet uses: crosscultural perspective" 2004" available at: http://www.allacademic.com/meta/p_mla_apa_research_citation/1/1/2/8/

[8] Dutton, William H., Ellen J. Helsper, and Monica M. Gerber "Oxford Internet survey: the Internet in Britain". Oxford: Oxford Internet Institute, University of Oxford. 2009.

[9] Glass, Z. "The effectiveness of product placement in video games", Journal of Interactive Advertising, 8(1), 2007, 111-134

[10] Haque, A and Khatibi, A. "E-Shopping: Current practices and future opportunities towards Malaysian customer perspective" Journal of Social Sciences, 1(1), .2005, 41-4

[11] Hills, P., \& Argyle, M. "Uses of the Internet and their relationships with individual differences in personality" Computers in Human Behavior, 19, 2003, 59-70

[12] Hongxiu Li and Reima Suomi, “ A Proposed Scale for Measuring E-service Quality” International Journal of u- and e-Service, Science and Technology" 2, ( 1), 2009.

[13] Hyejeong Kim, and Linda S. Niehm, "The Impact of Website Quality on Information Quality, Value, and Loyalty Intentions in Apparel Retailing”, Journal of Interactive Marketing, 23(2), 2009, 221-233

[14] Jones, Sydney and Susannah Fox “Generations online in 2009”. Washington, DC: Pew , 2009, Internet \& American Life Project Report. Available at: http://pewinternet.org/ /media//Files/Reports

[15] Kim, D., W. Kim and J. Han, “A perceptual mapping of online travel agencies and preference attributes”, Tourism management, 28, (2), 2007, 591-603.

[16] Kotler, P., and G. Armstrong. "Principles of Marketing" (New York): Management Decision, 50 (2), $2010, .253$ - 272

[17] Kumar, A.K "Term paper: Online Advertisement, "Hochschle Furtwangen University" . 2008. Retrieved from http://webuser.hsfurtwangen.de/ heindl/ebte-08ss- Online-Advertisement-kumar.pdf.

[18] Kuşay, Yeliz, , “Sosyal Medya'nın Gücü ve Uygulama Örnekleri, İkinci Medya Çă̆ında İnternet” Alfa Publication, 2010,61 -72.

[19] Liu, Chang and Kirk P. Arnett, "Exploring the Factor Associated with Web Site Success in the Context of Electronic Commerce," Information \& Management, 38, (1), 2000, 23-34.

[20] Loiacono, Eleanor T., Richard T. Watson, and Dale L. Goodhue "WebQualTM: A Measure of Web Site Quality," in Proceedings in Winter Educators Conference, Chicago, IL: American Marketing Association, 2002,.432-37

[21] Mathews, B. (2007), "Online social networking”, in Courtney, N. (Ed.), Library 2.0 and Beyond: Innovative Technologies and Tomorrow's user, Libraries Unlimited, Westport, CT.

[22] Ono, Hiroshi and Madeline Zavodny, "Race, Internet Usage and E-commerce." Federal Reserve Bank of Atlanta Working Paper, 2002, 1-17

[23] Ranganathan C, Ganapathy S,. "Key dimensions of business to consumer web sites". Information Management, 39(4), 2002,645765.

[24] Reid, M., \& Gray, C “online social networks, virtual communities, enterprises and information professionals” 15 (7), .2007.

[25] Rosenkrans, G.. The creativeness and effectiveness of online interactive rich media advertising, Journal of Interactive Advertising 9(2),2007. Retrieved from http://www.jiad.org/article49

[26] Saadeghvaziri, F. and Seyedjavadain, S. (2011) 'Attitude toward Advertising: Mobile Advertising Vs Advertising-in-General'. European Journal of Economics, Finance and Administrative Sciences, issue 28.

[27] Shu-Fen-Yu,. "Price perception of online airline tickets shoppers" Journal of Air transport Management-Elsevier. 14 (2), 2008,. 6669.

[28] Taylor, N.J.; and E.T. Loiacono; and R.T. Watson. Alternatives scenarios to the banner years, Communication of the Associations of the Computing Machinery (ACM) ,51(2), 2008, 53-58.

[29] Teo, Thompson S. H. "Demographic and motivation variables associated with Internet usage activities". Internet Research: Electronic Networking Applications and Policy, 11(2), 2001,125-137.

[30] Wise, K.;P.D. Bolls; H. Kim; A. Venkataraman; and R. Meyer. "Enjoyment of advergames and brand attitudes: The impact of thematic relevance", Journal of Interactive Advertising, 9(1), (2008, 27-36.

[31] Wolfinbarger, Mary and Mary C. Gilly, “eTailQ: Dimensionalizing, Measuring and Predicting Etail Quality,” Journal of Retailing, 79, (3), 2003, 183-98. 
[32] Yoo, C.Y. K. Kim; and P.A. Stout, "Assessing the effects of animation in online banner advertising: Hierarchy of effects model”, Journal of Interactive Advertising , 4, (2), .2004

[33] Yu, Y. T. and Dean, A., "The Contribution of Emotional Satisfaction To Customer Loyalty", International Journal of Service Industry Management, 12 (3), 2001, 234-250.

[34] Seyed Rajab Nikhashemi, Laily Paim, Ahasanul Haque, Ali Khatibi and Arun Kumar "Internet technology, CRM and Customer Loyalty": Customer satisfaction and retention perspectives. Middle-East Journal of Scientific Research 14 (1): (2013)

[35] Suranga Silva, Seyed Rajab Nikhashemi Ahasanul Haque Farzana Yasmin Khatibi, , "Critical Factors for Developing Brand Equity: An Empirical Investigation In Malaysia” IOSR Journal of Business Management, 1, (4), 2012,13-20 